\title{
Erythropoitein Increases In Vitro Motility and Vitality of Human Spermatozoa
}

\author{
BYRON ASIMAKOPOULOS, AGGELIKI TIPTIRI-KOURPETI and CHRYSSA METALINOU \\ Laboratory of Physiology, Faculty of Medicine, School of Health Sciences, \\ Democritus University of Thrace, Alexandroupolis, Greece
}

\begin{abstract}
Background/Aim: Erythropoietin and its receptor are expressed in the male reproductive system. Initial studies have shown that erythropoietin affects the motility of spermatozoa. The aim of the present study was to investigate the in vitro effect of erythropoietin in the motility and vitality of human spermatozoa. Materials and Methods: Forty-three semen samples, obtained after 2-4 days of abstinence from sex, were analyzed and processed using density gradient centrifugation. Aliquots containing one million of spermatozoa were treated with either erythropoietin, at concentrations of 10 and $100 \mathrm{mIU} / \mu \mathrm{l}$ or standard culture medium for one hour. Results: Progressive motility and vitality of spermatozoa significantly increased following treatment with erythropoietin. The effect was not dosedependent. Conclusion: The supplementation of culture medium with erythropoietin improves sperm processing in terms of vitality and motility. Future research should focus on the effects of erythropoietin on sperm capacitation as well as on the signal transduction pathways activated by erythropoietin and its receptor in spermatozoa.
\end{abstract}

Erythropoietin (EPO) is a highly glycosylated peptide produced mainly by the adult kidneys and fetal liver. The EPO gene encodes a protein of 193 amino acids and following cleavage the circulating protein consists of 165 amino acids with a molecular weight of $30.4 \mathrm{KDa}$ (1-3). EPO has a halflife of 7-8 $\mathrm{h}$ and its actions are mediated by a high-affinity transmembrane receptor (EPOR) (4). Binding of EPO to the EPOR induces a dimerization and/or reorientation of EPOR to

This article is freely accessible online.

Correspondence to: Byron Asimakopoulos, Laboratory of Physiology, Faculty of Medicine, School of Health Sciences, Democritus University of Thrace, Dragana, 68100 Alexandroupolis, Thrace, Greece. Tel: +30 2551030538, +30 2551030504, +30 6944368493, e-mail: basima@med.duth.gr

Key Words: Erythropoietin, motility, spermatozoa, vitality. a dimeric structure. The dominant signal transduction pathway activated by EPOR is the Jak/STAT (5-13).

EPO is the main regulator of erythropoiesis and its actions on bone marrow erythroid progenitor cells have been extensively studied $(1,4,8-10)$. Despite this, the detection of EPOR as well as the expression of EPO in other tissues and cells has revised the conventional notion on its biological functions. Among the sites where EPO and EPOR are expressed is the male reproductive system. EPO expression has been detected in the mouse epididymis (14), in Sertoli and peritubular myoid cells of rats (15). In rat Leydig cells, two receptors with different affinity to recombinant human EPO (rHuEPO) have been detected (16). In humans, EPO expression has been found in the testicular germ cell line (17) and can be measured in seminal plasma (18), while EPOR has been detected in human spermatozoa (19). In human Leydig cells, rHuEPO can directly stimulate testosterone production, an effect that seems to be independent of gonadotropin secretion (20). Akman et al., have managed to reduce the gonadotoxic effects of doxorubicin in adult male rats by administrating a longacting EPO analogue. The group found that following EPO analogue administration, the oxidative stress was reduced and the sperm motility and viability were improved (21).

Motility of spermatozoa is a crucial parameter of basic semen analysis and is related to natural conception but also to the successful outcome of assisted reproduction techniques (ART) (22-23). Sperm processing during ART aims to obtain an aliquot with a high percentage of vital and motile spermatozoa by removing immotile spermatozoa, somatic cells and seminal plasma. The use of sperm processing media that can support and enhance the motility and vitality of the selected spermatozoa is of significant importance. Therefore, the supplementation of sperm processing media with factors that can enhance motility and vitality can only be desirable.

In this study, we decided to investigate the in vitro effects of an EPO analogue on the motility and vitality of human spermatozoa selected after density gradient centrifugation and washing. 


\section{Materials and Methods}

The study was conducted in the Laboratory of Physiology, Faculty of Medicine, School of Health Sciences, Democritus University of Thrace, Alexandroupolis, Greece, as part of the research project "Study of the effects of growth factors on the motility and vitality of human spermatozoa" (MIS 5049528), during the period May 2020 February 2021. The study was approved by the Ethics Committee of Democritus University of Thrace $(\Delta \Pi \Theta / \mathrm{EH} \Delta \mathrm{E} / 58931 / 203)$.

Forty-three volunteers gave semen samples after 2-4 days of sexual abstinence. All of them signed an informed consent after receiving information about the study. The exclusion criteria were: i) severe astheno -, oligo- or teratozoospermia, ii) previous surgical interventions in the reproductive system or iii) receiving drugs with a potential impact on semen parameters. Each semen sample was subjected to basic semen analysis according to WHO guidelines (24), followed by sperm processing using a density gradient and washing. The pellet was suspended in Quinn's Sperm Washing Medium (SAGE In Vitro Fertilization, Inc., Trumbull, CT, USA) and sperm concentration as well as progressive motility were assessed. Subsequently, two aliquots, each with one million progressively motile spermatozoa were taken. The volume of each aliquot was finalized at $300 \mu \mathrm{l}$. One aliquot was incubated at $37^{\circ} \mathrm{C}$ for $1 \mathrm{~h}$ in culture medium (control) and the second aliquot was incubated, under the same conditions, in the culture medium supplemented with 10 or $100 \mathrm{mIU} / \mu \mathrm{l}$ of epoetin alpha (Binocrit, Sandoz Gmbh, Langkampfen, Austria). Therefore, there were two treatment groups: the one with the low and the other with the high concentration of EPO. Each experimental had its own paired control group as different volunteers participated in the low and high treatment groups. Immediately after $1 \mathrm{~h}$ incubation, the motility and vitality of the spermatozoa were assessed.

All operations were performed by the same person, under a laminar flow chamber (ESCO Class II, Type A2). Spermatozoa concentration was assessed using Improved Neubauer heamatocytometer (Poly-Optik $\mathrm{GmbH}$, Bad Blankenburg, Germany). For the motility assessment we used a NIKON Eclipse E200 (Nikon, Japan) microscope equipped with phase contrast lenses and a heating stage. For the sperm vitality assessment, we used eosin/nigrosin staining (Sigma-Aldrich Chemie Gmbh, Taufkirchen, Germany). Sperm aliquots were incubated in a Hera cell 150 (Thermo Electron Co, Langenselbold, Germany). Discontinuous density gradients were prepared using the density gradient system Sil-Select (Fertipro NV, Beernem, Belgium).

Statistical analysis was conducted using Statistica 6.0 (StatSoft Inc., Tulsa, OK, USA). Wilcoxon matched pairs test was used for the comparisons between controls and treatment groups. Mann-Whitney $U$-test was used for the comparisons between the groups of the low and high concentration of EPO. The significant level was set at 0.05 . The values in the text and Tables are presented as mean \pm standard deviation.

\section{Results}

Twenty-one volunteers, 18 to 45 years old, gave semen samples for the experiments with the low concentration of EPO $(10 \mathrm{mIU} / \mu \mathrm{l})$. Treatment with EPO significantly improved sperm's progressive motility, non-progressive motility and vitality compared to controls (Table I). Namely, the progressive motility with EPO was $10.048 \pm 6.078 \%$ and the vitality was $11.238 \pm 6.300 \%$ higher compared to that of the untreated sperm.
Table I. Motility and vitality improvement of spermatozoa treated with $10 \mathrm{mIU} / \mu \mathrm{l}$ EPO. Values show mean \pm standard deviation $(N=21)$.

\begin{tabular}{lccc}
\hline & EPO $10 \mathrm{mIU} / \mu \mathrm{l}$ & Control & $p$-Value \\
\hline Progressive motility & $47.524 \pm 13.303$ & $37.476 \pm 12.339$ & 0.000 \\
Non-progressive motility & $13.762 \pm 4.036$ & $10.000 \pm 4.528$ & 0.001 \\
Immotile & $39.429 \pm 12.600$ & $52.048 \pm 11.280$ & 0.000 \\
Vitality & $70.905 \pm 7.569$ & $59.667 \pm 9.441$ & 0.000 \\
\hline
\end{tabular}

Table II. Motility and vitality improvement of spermatozoa treated with $100 \mathrm{mIU} / \mu \mathrm{l}$ EPO. Values show mean \pm standard deviation $(N=22)$.

\begin{tabular}{lccc}
\hline & EPO $100 \mathrm{mIU} / \mu \mathrm{l}$ & Control & $p$-Value \\
\hline Progressive motility & $40.045 \pm 8.437$ & $27.364 \pm 10.060$ & 0.000 \\
Non progressive motility & $10.455 \pm 6.139$ & $8.500 \pm 3.609$ & 0.281 \\
Immotile & $49.500 \pm 8.146$ & $64.136 \pm 9.280$ & 0.000 \\
Vitality & $71.227 \pm 6.747$ & $59.136 \pm 6.777$ & 0.000 \\
\hline
\end{tabular}

For the experiments with the high concentration of EPO $(100 \mathrm{mIU} / \mu \mathrm{l})$, semen samples from 22 volunteers, aged 19 to 51 years old, were used. Again, EPO significantly improved the progressive motility and vitality compared to controls (Table II). Non-progressive motility, although higher with EPO, was not significantly different from that of the untreated sperm. EPO improved the progressive motility by $12.682 \pm 4.110 \%$ and the vitality by $12.091 \pm 4.492 \%$.

In order to compare the effects of the low vs. the high concentration of EPO, the differences in progressive motility and vitality between the controls and the two groups of EPO were extracted. Although with the high concentration of EPO there was a trend for greater improvement in both progressive motility and vitality, the statistical analysis showed that this was not significant (progressive motility: $\mathrm{U}=167.500, p=0.123$; vitality: $\mathrm{U}=229.000, p=0.971$ ).

\section{Discussion}

The detection of EPO protein and its receptor in the male reproductive system has put forward the question of its physiological role in reproductive functions. Early in vivo studies have shown that EPO has a stimulatory effect in Leydig cells leading to an increased testosterone production in rats and humans $(20,25)$. In nephrectomized rats, EPO administration can alleviate steroidogenesis, spermatogenesis, epididymal sperm maturation and fertility (26). The experiments of Akman et al. in adult rats have shown that in vivo administration of an EPO analogue protects spermatogenesis from the known gonadotoxic effects of Doxorubicin that leads to the formation of free radicals, 
suggesting that EPO exerts antioxidant properties (21). In this study, the adult rats treated with EPO analogue had sperm with improved motility and vitality compared to rats treated with Doxorubicin only (21). In another experimental study using adult rats with testicular torsion/detorsion, in vivo administration of an EPO analogue prevented testicular damage and reduced oxidative makers again, suggesting that EPO may be acting as a direct and/or indirect antioxidant (27). On the other hand, the EPO gene transfer or EPO administration in male rabbits had no significant effects on sperm concentration, motility or vitality (28).

The expression of EPOR in human spermatozoa as well as the presence of EPO protein in semen plasma triggers questions on their role in the ejaculated sperm and their possible effects in sperm motility and vitality after in vitro treatment. The results of the present study show that EPO, as a supplement in the sperm-processing medium, can increase the progressive motility and vitality of human spermatozoa after $1 \mathrm{~h}$. In our experiments, we used washed spermatozoa thus we removed the native EPO present in semen plasma which allowed us to test the EPO effects by comparing spermatozoa incubated in two doses of EPO against spermatozoa incubated in EPO-free medium. These effects were not dose-dependent, at least not on the two doses used in the present study. In the only other similar study published, Tug et al. have examined the effects of EPO on sperm motility by incubating human spermatozoa in various concentrations of EPO: 0.1, 1, 10, $100 \mathrm{mIU} / \mathrm{ml}$ for 4 $\mathrm{h}$ (29). They found improvement in the sperm's progressive motility at all concentrations except the lowest one $(0.1$ $\mathrm{mIU} / \mathrm{ml}$ ) (29). Comparing our results with those of Tug et al. (29) we should first note that the positive effect of EPO on motility is confirmed, except that they realized there is a minimum concentration that can act on sperm's motility. Secondly, the differences in the design of the two studies possibly are behind the different results regarding the dose dependence; Tug et al. (29) used EPO at concentrations from 0.1 to $100 \mathrm{mIU} / \mathrm{ml}$ and incubated spermatozoa for four hours while in our study we used higher concentrations of EPO (10 $\mathrm{mIU} / \mu \mathrm{l}$ and $100 \mathrm{mIU} / \mu \mathrm{l})$ and the incubation time was $1 \mathrm{~h}$. It is worth to mention that we decided on a 1-h sperm incubation in EPO in an attempt to mimic the conditions of human-assisted reproduction, where sperm processing is usually performed within $1 \mathrm{~h}$ after the delivery of the semen sample (24).

In our study, as already mentioned, an increase in spermatozoa vitality was observed following incubation with EPO. To our knowledge, this is the first report showing this effect in human sperm. The underlying mechanisms responsible for the effects of EPO on the motility and vitality of ejaculated spermatozoa are not known. It could be hypothesized that the binding of EPO to its receptor located in the plasma membrane of spermatozoa activates signaling pathways resulting in the protection of spermatozoa from reactive oxygen species and apoptosis or the enhancement of mitochondrial function, thus, resulting in better motility. Especially for the sperm's motility, it is not known whether EPO has an effect as an antiapoptotic/antioxidant agent or it acts on the sperm's motility per se. The antiapoptotic effect of EPO through activation of its receptor has been shown in erythroid precursor cells (30-31) and there are indications of antioxidant effects from previous studies $(21,27)$. The study of EPOR in the plasma membrane of spermatozoa and the signal transduction pathways activated by the binding of EPO to EPOR could shed some light into the mechanism behind increased sperm motility and vitality. Currently, there is no knowledge of either the precise location of EPOR in the cell membrane of spermatozoa or the downstream signaling pathways. The investigation of this topic could contribute, not only to a clear understanding of the mechanisms behind the improvement of motility and vitality following an in vitro treatment with EPO, but also to a better understanding of the physiology of spermatozoa.

In conclusion, the present study showed that treatment of ejaculated spermatozoa with EPO can significantly improve their progressive motility, confirming the findings of a previous study (29). It also showed, for the first time, that treatment with EPO can significantly increase sperm's vitality in vitro. According to our results, these effects are not dose-dependent. To our opinion, future research should focus on the EPOR expressed on the cell membrane of spermatozoa and the signal transduction pathways involved in their motility and vitality. The effects of EPO on the induction of capacitation and acrosome reaction are two other topics for future research as they are both critical for fertilization.

\section{Conflicts of Interest}

The Authors declare no potential conflicts of interest in relation to this study.

\section{Authors' Contributions}

B A was involved in the study's conception and design, data analysis and writing of the manuscript. A $\mathrm{T} \mathrm{K}$ performed the experiments, data acquisition and analysis. $\mathrm{C} \mathrm{M}$ contributed substantially to data acquisition and revision of the manuscript.

\section{Acknowledgements}

This research was co-financed by Greece and the European Union (European Social Fund) through the Operation Program "Human Resources Development, Education and Lifelong Learning 2014-2020" in the context of the project "Study of the effects of growth factors on the motility and vitality of human spermatozoa" (MIS 5049528).

The Authors thank all the sperm donors who contributed to this study. 


\section{References}

1 Lacombe C and Mayeux P: The molecular biology of erythropoietin. Nephrol Dial Transplant 14(Suppl 2): 22-28, 1999. PMID: 10334664 . DOI: $10.1093 /$ ndt/14.suppl_2.22

2 Jacobs K, Shoemaker C, Rudersdorf R, Neill SD, Kaufman RJ, Mufson A, Seehra J, Jones SS, Hewick R and Fritsch EF: Isolation and characterization of genomic and cDNA clones of human erythropoietin. Nature 313(6005): 806-810, 1985. PMID: 3838366. DOI: $10.1038 / 313806 a 0$

3 Lin FK, Suggs S, Lin CH, Browne JK, Smalling R, Egrie JC, Chen KK, Fox GM, Martin F and Stabinsky Z: Cloning and expression of the human erythropoietin gene. Proc Natl Acad Sci USA 82(22): 7580-7584, 1985. PMID: 3865178. DOI: 10.1073/pnas.82.22.7580

4 Bunn HF: Erythropoietin. Cold Spring Harb Perspect Med 3(3): a011619, 2013. PMID: 23457296. DOI: 10.1101/cshperspect. a011619

5 Livnah O, Stura EA, Middleton SA, Johnson DL, Jolliffe LK and Wilson IA: Crystallographic evidence for preformed dimers of erythropoietin receptor before ligand activation. Science 283(5404): 987-990, 1999. PMID: 9974392. DOI: 10.1126/ science.283.5404.987

6 Philo JS, Aoki KH, Arakawa T, Narhi LO and Wen J: Dimerization of the extracellular domain of the erythropoietin (EPO) receptor by EPO: one high-affinity and one low-affinity interaction. Biochemistry 35(5): 1681-1691, 1996. PMID: 8634300. DOI: $10.1021 / \mathrm{bi} 9524272$

7 Syed RS, Reid SW, Li C, Cheetham JC, Aoki KH, Liu B, Zhan $\mathrm{H}$, Osslund TD, Chirino AJ, Zhang J, Finer-Moore J, Elliott S, Sitney K, Katz BA, Matthews DJ, Wendoloski JJ, Egrie J and Stroud RM: Efficiency of signalling through cytokine receptors depends critically on receptor orientation. Nature 395(6701): 511-516, 1998. PMID: 9774108. DOI: 10.1038/26773

8 Watowich SS, Hilton DJ and Lodish HF: Activation and inhibition of erythropoietin receptor function: role of receptor dimerization. Mol Cell Biol 14(6): 3535-3549, 1994. PMID: 8196600. DOI: $10.1128 / \mathrm{mcb} \cdot 14.6 .3535-3549.1994$

9 Watowich SS: The erythropoietin receptor: molecular structure and hematopoietic signaling pathways. J Investig Med 59(7): 1067-1072, 2011. PMID: 21307776. DOI: 10.2310/JIM.0b01 $3 \mathrm{e} 31820 \mathrm{fb} 28 \mathrm{c}$

10 Watowich SS, Yoshimura A, Longmore GD, Hilton DJ, Yoshimura $\mathrm{Y}$ and Lodish HF: Homodimerization and constitutive activation of the erythropoietin receptor. Proc Natl Acad Sci USA 89(6): 2140-2144, 1992. PMID: 1312714. DOI: 10.1073/pnas.89.6.2140

11 Darnell JE Jr, Kerr IM and Stark GR: Jak-STAT pathways and transcriptional activation in response to IFNs and other extracellular signaling proteins. Science 264(5164): 1415-1421, 1994. PMID: 8197455 . DOI: $10.1126 /$ science. 8197455

12 Darnell JE Jr: STATs and gene regulation. Science 277(5332): 1630-1635, 1997. PMID: 9287210. DOI: 10.1126/science. 277.5332 .1630

13 Hibi M and Hirano T: Signal transduction through cytokine receptors. Int Rev Immunol 17(1-4): 75-102, 1998. PMID: 9914944. DOI: $10.3109 / 08830189809084488$

14 Kobayashi T, Yanase H, Iwanaga T, Sasaki R and Nagao M: Epididymis is a novel site of erythropoietin production in mouse reproductive organs. Biochem Biophys Res Commun 296(1):
145-151, 2002. PMID: 12147241. DOI: 10.1016/s0006-291x(02) 00832-x

15 Magnanti M, Gandini O, Giuliani L, Gazzaniga P, Marti HH, Gradilone A, Frati L, Aglianò AM and Gassmann M: Erythropoietin expression in primary rat Sertoli and peritubular myoid cells. Blood 98(9): 2872-2874, 2001. PMID: 11675366. DOI: 10.1182/blood.v98.9.2872

16 Elliott S, Pham E and Macdougall IC: Erythropoietins: a common mechanism of action. Exp Hematol 36(12): 1573-1584, 2008. PMID: 18922615. DOI: 10.1016/j.exphem.2008.08.003

17 Ascensao JL, Gaylis F, Bronson D, Fraley EE and Zanjani ED: Erythropoietin production by a human testicular germ cell line. Blood 62(5): 1132-1134, 1983. PMID: 6684961.

18 Temma K, Shimoya K, Hashimoto K, Zhang Q, Koyama M and Murata Y: Detection of erythropoietin in human seminal plasma. Fertil Steril 81(Suppl 1): 798-801, 2004. PMID: 15019812. DOI: 10.1016/j.fertnstert.2003.07.039

19 Tug N, Kilic U, Karateke A, Yilmaz B, Ugur M and Kilic E: Erythropoietin receptor-like immunostaining on human spermatozoa. Reprod Biomed Online 21(5): 718-720, 2010. PMID: 20884294. DOI: 10.1016/j.rbmo.2010.05.022

20 Foresta C, Mioni R, Bordon P, Miotto D, Montini G and Varotto A: Erythropoietin stimulates testosterone production in man. $\mathrm{J}$ Clin Endocrinol Metab 78(3): 753-756, 1994. PMID: 8126153. DOI: $10.1210 /$ jcem.78.3.8126153

21 Akman O, Özkanlar Y, Özkanlar S, Oruc E, Ulas N, Ziypak T, Lehimcioğlu NC, Türkeli M and Ucar Ö: Erythropoietin hormone and ACE inhibitor protect the sperm parameters of adult male rats against Doxorubicin toxicity. Kafkas Univ Vet Fak Derg 21(6): 805-812, 2015. DOI: 10.13140/RG.2.1.4076.0488

22 Jouannet P, Ducot B, Feneux D and Spira A: Male factors and the likelihood of pregnancy in infertile couples. I. Study of sperm characteristics. Int J Androl 11(5): 379-394, 1988. PMID: 3235207. DOI: 10.1111/j.1365-2605.1988.tb01011.x

23 Larsen L, Scheike T, Jensen TK, Bonde JP, Ernst E, Hjollund NH, Zhou Y, Skakkebaek NE and Giwercman A: Computerassisted semen analysis parameters as predictors for fertility of men from the general population. The Danish First Pregnancy Planner Study Team. Hum Reprod 15(7): 1562-1567, 2000. PMID: 10875866. DOI: 10.1093/humrep/15.7.1562

24 WHO laboratory manual for the examination and processing of human semen. Fifth edition. World Health Organization 2010. The Press Syndicate of the University of Cambridge, Cambridge UK. Available at: https://www.who.int/publications/i/item/ 9789241547789 [Last accessed on July 1, 2021]

25 Mioni R, Gottardello F, Bordon P, Montini G and Foresta C: Evidence for specific binding and stimulatory effects of recombinant human erythropoietin on isolated adult rat Leydig cells. Acta Endocrinol (Copenh) 127(5): 459-465, 1992. PMID: 1471458. DOI: $10.1530 /$ acta.0.1270459

26 Yamamoto Y, Sofikitis N and Miyagawa I: Effects of erythropoietin, bromocryptine and hydralazine on testicular function in rats with chronic renal failure. Andrologia 29(3): 141-144, 1997. PMID: 9197918. DOI: 10.1111/j.1439-0272.1997.tb00308.x

27 Akcora B, Altug ME, Kontas T and Atik E: The protective effect of darbepoetin alfa on experimental testicular torsion and detorsion injury. Int J Urol 14(9): 846-850, 2007. PMID: 17760753. DOI: 10.1111/j.1442-2042.2007.01844.x

28 Collares TF, Campos VF, Urtiaga G, Leon PM, Amaral MG, Hartleben CP, McBride AJ, Dellagostin OA, Deschamps JC, 
Seixas FK and Collares T: Erythropoietin non-viral gene therapy does not affect motility, viability, morphology or concentration of rabbit sperm. Animal 7(5): 778-783, 2013. PMID: 23171533. DOI: $10.1017 / \mathrm{S} 1751731112002157$

29 Tug N, Altunkaynak ME, Aktas RG, Kilic U, Yilmaz B, Cam C and Karateke A: Does erythropoietin affect motility of spermatozoa? Arch Gynecol Obstet 281(5): 933-938, 2010. PMID: 19937447. DOI: 10.1007/s00404-009-1289-4

30 Kelley LL, Green WF, Hicks GG, Bondurant MC, Koury MJ and Ruley HE: Apoptosis in erythroid progenitors deprived of erythropoietin occurs during the G1 and S phases of the cell cycle without growth arrest or stabilization of wild-type p53. Mol Cell Biol 14(6): 4183-4192, 1994. PMID: 8196656. DOI: 10.1128/mcb.14.6.4183-4192.1994
31 Konstantinopoulos PA, Karamouzis MV and Papavassiliou AG: Selective modulation of the erythropoietic and tissue-protective effects of erythropoietin: time to reach the full therapeutic potential of erythropoietin. Biochim Biophys Acta 1776(1): 1-9, 2007. PMID: 17683868. DOI: 10.1016/j.bbcan.2007.07.002

Received May 12, 2021

Revised July 1, 2021

Accepted July 13, 2021 